\title{
A new method for modelling roofing materials emissions on the city scale: Application for zinc in the city of Créteil (France)
}

\author{
Emna Sellami-Kaaniche ${ }^{1,2}$, Bernard de Gouvello ${ }^{1,2}$, Marie-Christine Gromaire ${ }^{2}$ and Ghassan Chebbo ${ }^{2}$
}

\author{
${ }^{1}$ Centre Scientifique et Technique du Bâtiment (CSTB), 11 rue Henri Picherit, BP 8234144323 Nantes Cedex, \\ France: e-mail: sellamie@leesu.enpc.fr \\ ${ }^{2}$ Université Paris-Est, LEESU (UMR MA 102), UPEC, UPEMLV, ENPC, AGROPARISTECH, F77455 ou \\ F94010, 6-8 avenue Blaise Pascal, Cité Descartes - Champs sur Marne, MARNE LA VALLEE CEDEX 2, \\ France
}

\begin{abstract}
Today, urban runoff is considered as an important source of environmental pollution. Roofing materials, in particular the metallic ones, are considered as a major source of urban runoff metal contaminations. In the context of the European Water Directive (2000/60 CE), an accurate evaluation of contaminant flows from roofs is thus required on the city scale, and therefore the development of assessment tools is needed. However, on this scale, there is an important diversity of roofing materials. In addition, given the size of a city, a complete census of the materials of the different roofing elements represents a difficult task. Informations relating roofing materials and their surfaces on an urban district do not currently exist in urban databases. The objective of this paper is to develop a new method of evaluating annual contaminant flow emissions from the different roofing material elements (ex: gutter, rooftop) on the city scale. This method is based on using and adapting existing urban databases combined with a statistical approach. Different rules for identifying the materials of the different roofing elements on the city scale have been defined. The methodology is explained through its application to the evaluation of zinc emissions on the scale of the city of Créteil.
\end{abstract}

Key words: City scale, modelling, emissions, roofing material, zinc, contaminant

\section{Introduction}

In the city, pollutants released into the runoff by urban infrastructure, are considered as a major source of receiving water contaminations (Ellis and Hvitved Jacobsen, 1996; Saget et al., 1995). Many studies developed since 1990 have highlighted the pollution from roofing materials in urban runoff (Bertling et al., 2006; Förster, 1996; Gromaire-Mertz et al., 1999; Odnevall Wallinder et al., 1998; Quek and Förster, 1993). In this context, the OPUR (Observatory of Urban Pollutants in Ile-de-France) program focused on identifying and quantifying the emissions of different pollutants ( $\mathrm{Zn}, \mathrm{Pb}$, biocides...) from roofing materials runoff on the test-bed, roof and small urban catchment scales (Gromaire et al., 2011; Gromaire-Mertz et al., 1999; Robert-Sainte et al., 2009; Van de Voorde, 2012). In these studies, the evaluation of pollutant emissions was limited to small scaled catchments. However, the city scale is characterized by big diversity and large number of buildings with different roofing materials. This diversity depends extremely on the history of the building (age, renewal), the urban planning (land use, building typology...), the social characteristics, the town regulation framework...To date, no study has been conducted to evaluate the roofing material emissions in urban runoff on the city scale. Today, in the context of the European Water Directive (2000/60 CE), which aims at achieving a good environmental status of aquatic environments until 2015, it is important to evaluate roofing material pollutant flows on the city scale. For this task, a specific model is needed.

Existing roofing material emission models were elaborated on the scale of test-beds. Annual average pollutant runoff rates have been evaluated for different roofing materials (Bertling et al., 2006; Leuenberger-Minger et al., 2002; Odnevall Wallinder et al., 2004; Robert-Sainte et al., 2009; Van de Voorde, 2012).

To model the emission on the city scale, new parameters related to the large scale have to be taken into account. An important part of the modelling is based on identifying and quantifying roofing material areas on a city. However, on the city scale, the information concerning roofing materials and their surfaces on an urban district does not currently exists in urban databases Some methods have already been developed for the evaluation of roof surfaces on a large-scale in order to study building-integrated solar-energy applications (Bergamasco and Asinari, 2011; Izquierdo et al., 2008) or to explore the potential of green infrastructure in adapting cities for climate change (Gill et al., 2006). But, in these studies, the roofing materials were not taken into account. Other approaches (Gromaire et al., 2002a; Le Bris and Robert-Sainte, 2009) have evaluated roofing material areas using data obtained from aerial photographs and image classification software. The classification method based on aerial images was applied to an urban catchment with $2.25 \mathrm{~km}^{2}$ of surface (Le Bris and Robert-Sainte, 2009). Nevertheless, this classification method presents some limitations especially in terms of confusion between different materials (e.g. zinc in the shadow and slates in the sun). In addition, the identification of the material is 
limited to the input data. For example, if three types of roofing materials are defined in the input data, the model will try to classify all roofing materials into the three types and will not be able to recognize another material. Moreover, the roofing material age is not identified. Finally, from an aerial image, only rooftop material areas can be evaluated. Besides, roof is also composed of other small elements (ex: gutter and valley) which can be a large source of runoff contamination. These elements are generally not visible on the aerial photography.

Therefore, a method must be developed to evaluate roofing material contaminant emissions on the city scale. This method is based on the use of urban knowledge, the adaptation of existing urban databanks in the city and the definition of new approaches.

The objective of this paper is to describe the method evaluating roofing material emissions on the city scale by studying the zinc emissions in the city of Créteil. This application in Créteil has two objectives. The first one is to validate the methodology. The second one is to analyze the transferability of the method to other cities and also to other contaminants. The development of the method from Créteil has enabled us to produce different methodological principles and practical rules.

\section{Methodological Principles}

This part describes the general methodology of the work, applicable to any contaminant. It is thus illustrated by examples for different contaminants.

\subsection{General method to evaluate contaminant annual flow emitted by roofing material on the city scale}

To evaluate roofing material contaminant emission on the city scale, the equation of its annual flow emitted by roofing material on the city scale is needed.

On the city scale, two parameters which determine the roofing material contaminant emissions have been retained: the surface or the length of the different materials used for the different roofing elements and the annual runoff rate for each contaminant from these materials.

The method developed to evaluate these parameters is described in figure 1. The different parts of this method will be explained in the following sections of this paper.

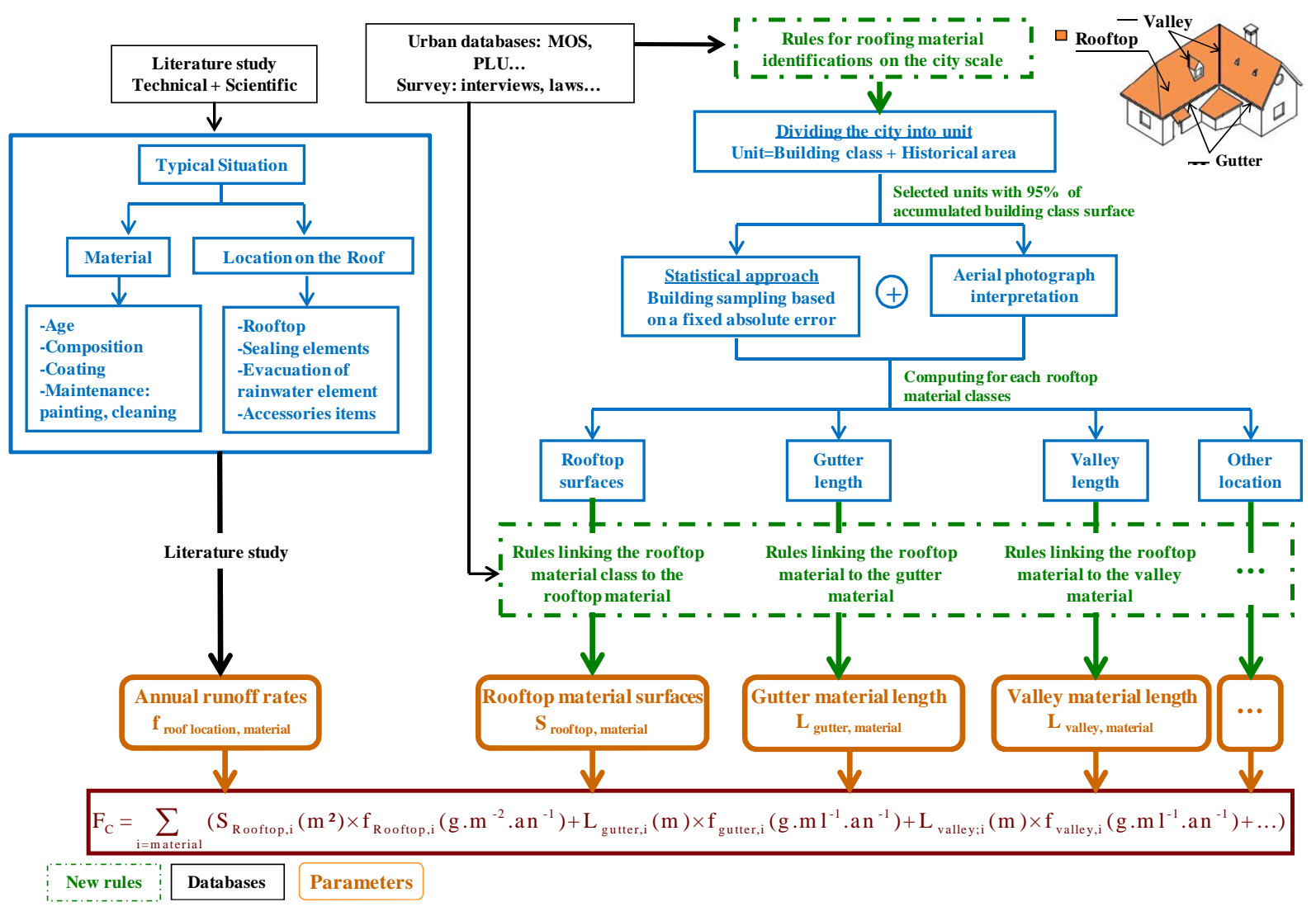

Figure 1: General method to evaluate contaminant annual flow emitted by roofing material on the city scale

In order to model the contaminant emissions on the city scale, describing and understanding the emission on the roof scale is needed. Thus, a new concept called typical situation of contaminant emission from roofing material on the roof scale has been defined. This concept allows the transition between the roof scale and the city scale. For each typical situation a contaminant annual runoff rate is associated. 
A new method has been developed to identify and quantify roofing material surfaces or lengths on the city scale. This method is based on two main steps. The first one consists in quantifying the surfaces of rooftop materials classes $^{l}$ and their associated valley and gutter lengths. The second one is the quantification of the rooftop material surfaces, gutter material lengths and valley material lengths using specific rules (Figure 1).

\subsection{Annual runoff rates and typical situations of contaminant emission from roofing materials}

A typical situation of contaminant emission from roofing materials on the roof scale is a situation for which a unique annual runoff rate for a contaminant is associated. On the roof scale, different parameters influence the contaminant runoff rate from roofing materials. These parameters can be classified into parameters related to the roof characteristics and parameters related to the exposure conditions and the time-related factors. The roof characteristics include material characteristics (age, type and composition) (Bertling et al., 2006; Odnevall Wallinder et al., 2001), the roofing element (gutter, rooftop...) (Robert-Sainte et al., 2009), inclination and orientation (Odnevall Wallinder et al., 2000). On the city scale, the material characteristics should be taken into account. However, the orientation effects become smoothed as all types of roof orientations are combined. The roof slope was shown to be determinant for the runoff rate per $\mathrm{m}^{2}$ of exposed material yet does not significantly affects the runoff rate per $\mathrm{m}^{2}$ of projected area (Odnevall Wallinder et al., 2000). On the city scale, identifying roofing materials is based on aerial photography databases which provide only projected area measurements. Thus, roof inclination will not be taken into account. The different roofing elements do not have the same contaminant runoff rate (Robert-Sainte et al., 2009) due to different collected runoff volumes, so the contaminant location on the roof is an important parameter to be taken into consideration on the city scale. In addition, contaminant runoff rates depend on exposure duration, rainfall characteristics (value, intensity, duration, $\mathrm{pH}$ ) and a parameter considering previous exposure period (Gromaire et al., 2011).

These parameters are not taken into account in our case because we are focusing on annual contaminant runoff rate values. So for a city scale evaluation, two types of parameters seem relevant. The first one concerns material characteristics (age, type and composition) and the second one is the location on the roof. Thus, each typical situation of contaminant emission from roofing materials on the roof scale is defined as a simple case of a contaminant emission characterized by its belonging to a specific material and its location on the roof (see Table 1). The contaminant runoff rate for this typical situation will be noted $\boldsymbol{r}_{\text {material, }}$ rooflocation .

Table 1: Examples of typical situations

\begin{tabular}{|c|c|c|c|c|c|}
\hline \multirow{2}{*}{ Pollutant } & \multicolumn{3}{|c|}{ Material } & \multirow{2}{*}{$\begin{array}{l}\text { Location on } \\
\text { the roof }\end{array}$} & \multirow{2}{*}{ Annual runoff rate } \\
\hline & Type & Age & Form & & \\
\hline Chrome & $\begin{array}{c}\text { Stainless } \\
\text { steel }\end{array}$ & new & $\begin{array}{l}\text { Component of stainless } \\
\text { steel sheet }\end{array}$ & Rooftop & $\begin{array}{c}0,8 \text { à } 1,2\left(\mathrm{mg} \cdot \mathrm{m}^{-2} \mathrm{an}^{-1}\right)(\text { Odnevall } \\
\text { Wallinder } \text { et al., 2002) }\end{array}$ \\
\hline Lead & Copper & old & $\begin{array}{c}\text { Component of copper } \\
\text { sheet }\end{array}$ & Gutter & $\begin{array}{c}0,9\left(\mathrm{mg} \cdot \mathrm{ml}^{-1} \cdot \text { an }^{-1}\right) \\
(\text { Robert-Sainte } \text { et al., 2009) }\end{array}$ \\
\hline Zinc & $\begin{array}{c}\text { Zinc } \\
\text { natural }\end{array}$ & new & $\begin{array}{l}\text { Principal component of } \\
\text { zinc sheet }\end{array}$ & Gutter & $\begin{array}{c}0,871 \\
\text { (Robert-Sainte } \text { et al., 2009) }\end{array}$ \\
\hline
\end{tabular}

\subsubsection{Belonging to a specific material}

\section{- Material age}

Runoff rates depend on the age of the material. On the one hand, the material composition depends on the period of its production. For example, a tin-lead component was added to the stainless steel composition in 1971 (Invernizzi, 2000). On the other hand, old materials present different runoff rates from the new material. For example, copper emission are higher for the older material $\left(2,1 \mathrm{~g} \cdot \mathrm{m}^{-2} \mathrm{an}^{-1}\right.$ for copper 40 year old and $1,3 \mathrm{~g} \cdot \mathrm{m}^{-2} \mathrm{an}^{-1}$ for new copper) (He et al., 2001), whereas for paint containing biocides, the biocide runoff rate decreases from rain to another due to the limited quantity of biocide in the paint (Jungnickel et al., 2008).

\section{- $\quad$ Sources of pollutants in roofing materials}

A pollutant released from a roofing material has a specific form of presence in the material. The pollutant can be the principal or a secondary component in the material composition. This is the case of metal materials (e.g. zinc, copper and lead) which are based on specific alloys composed of different components with different proportions. For example, steel is an alloy of iron and other elements such as nickel (Invernizzi, 2000). This is also the case of other roofing materials. For instance, bituminous membranes contain polycyclic aromatic hydrocarbons (PAHs) (Bowen and de Groot, 2000).

The pollutant can also be a component in the coating added to the material during the production process. For example, zinc as a pollutant, releases from galvanized steel (Bertling et al., 2006), i.e. steel coated with a thin zinc layer.

\footnotetext{
${ }^{1}$ A material class is defined as the gathering of different materials having the same principal material. For example, steel is considered as a class which gathers different varieties of steel: natural steel, galvanised steel, stainless steel, coated steel.
} 
In addition, roofing material maintenance practises may be sources of pollutants. For example, renders and paints contain biocides which leached during rainfall periods (Burkhardt et al., 2007; Jungnickel et al., 2008; Schoknecht et al., 2009). Benzalkonium is a pollutant widely used as a demossing agent for cleaning tile roofs. This practice leads to benzalkonium transfer into stormwater (Van de Voorde et al., 2012).

To conclude, a pollutant may come from three different sources: the material itself, the coating of the material and the roofing maintenance practices.

\subsubsection{Location on the roof}

A roof is composed of four main elements: the rooftop, the tightness elements (valley, ridge, hips...), the evacuation of rainwater elements (gutter, pipes...) and accessories items (fixing components for slates...). For the same material, each element of the roof has a specific runoff rate. For instance, runoff rate for lead flashing against sidewall $\left(0,88 \mathrm{~g} \cdot \mathrm{m}^{-2} \cdot \mathrm{y}^{-1}\right)$ is very much lower than from rooftop lead $\left(5,23 \mathrm{~g} \cdot \mathrm{m}^{-2} \cdot \mathrm{y}^{-1}\right)$ due to orientation and shelter effect (Wilson, 2003). In addition, runoff rate from zinc rooftop $\left(3,868 \mathrm{~g} \cdot \mathrm{m}^{-2} \cdot \mathrm{y}^{-1}\right)$ is higher than from gutter zinc $\left(1,654 \mathrm{~g} \cdot \mathrm{m}^{-2} \cdot \mathrm{y}^{-1}\right)$ (Robert-Sainte et al., 2009).

We should note that the production of runoff rates on the roof scale is not the objective of our work. However, the existing runoff rates in the literature will be used to model the contaminant flow on the city scale.

\subsection{Identification and quantification of roofing material elements on the city scale}

A new method has been developed to identify and quantify roofing material surfaces or lengths on the city scale. This method is based on two approaches. The first one is a survey made by conducting interviews with the actors of the roofing material sector (industrials, master work, architect...) and consulting different documents (e.g. town planning regulation framework, construction laws, standardized technical documents). From this survey, concrete rules for the identification of roofing materials on the city scale have been established. The second one is a statistical approach for estimating the distribution of the materials of the different roofing elements on the city scale. The two approaches are combined in the method.

In figure 1, the first step of the method consists in dividing the city into homogeneous urban units. Each unit is obtained by crossing:

- "Building classes" established through the adaptation of an existing land use database which allows us to connect building scale and urban scale;

- With the historical urbanization process of the city.

The crossing is conducted using specific rules which are based on three hypotheses:

- The choice of a roofing material depends on the building typology.

- The spatial and temporal urban evolution of the city influences the use of roofing materials.

- The town regulation framework allows/recommends some roofing materials in the city.

Each "Building class" located in an historical area represents a unit. For each unit, a random sampling technique is elaborated from the available building database. To ensure an absolute error less than $3 \%$, the number of the selected random building depends on the total number of the existing building in the unit. This step provides the distribution of the rooftop material classes (ex: zinc, tile) and the gutter and valley lengths for each rooftop material class in each unit.

In a second step, the material of the different roofing elements in each unit is quantified using a new set of rules. Three types of rules have been used:

- Rules linking the rooftop material class to the rooftop material: these rules allow us to distinguish between the different varieties of the material class. For example, if the proportion of steel (as a material class) was identified in a specific unit, the objective is to get the distribution between galvanised steel, coated steel and stainless steel. In the case of units based on industrial building, the obtained rule is "coated steel is used in industrial unit".

- Rules linking the rooftop material to the gutter material: for a rooftop material there is a specific use of the gutter material. Thus, the obtained rule is "in metallic roof the gutter has the same material as the rooftop".

- Rules linking the rooftop material to the valley material: for a rooftop material there is a specific use of the valley material. Thus, the obtained rule is "in metallic roof the valley has the same material as the rooftop".

Finally, for each unit the rooftop material surface area distributions and the valley and gutter material lengths are computed. Thus, contaminant annual flow emitted in roofing material runoff on the city scale is computed by multiplying the surface or the length of the material element by its associated runoff contaminant rate.

All of these rules will be explained in the next part by studying the zinc emission in the city of Créteil. In fact, the different rules are sometimes global or specific to the site. Thus, it will be easier to understand them by studying a case study.

\section{Application of the methodology for zinc emissions in the city of Créteil}

\subsection{Case Study Site}

The goal of our research work is to develop a general method to quantify roofing material surfaces or lengths on the city scale. In this context, a case study is needed to achieve two objectives. The first one is to validate the method. The second one is to make it possible to apply the method to other cities. Therefore, a sufficiently 
complex case study should be chosen in order to represent most of the urban functions of any city. In fact, the city should present a sufficient urban diversity. The selected city is Créteil located about $10 \mathrm{~km}$ from Paris (France). Créteil with a total area of $11.5 \mathrm{~km}^{2}$ (INSEE, 2008), presents a big diversity and a large number of buildings which represents about $24 \%$ of the city area. This city also presents an interesting urban and functional diversity (residential area, industrial area...).

To quantify the different roofing material surfaces or lengths, urban data banks (historical urban map), land use database MOS-IAU ${ }^{2}$ have been reorganized in order to match with our objective and interviews that have been conducted with various actors such as masters of work, contracting authorities and architects. These interviews showed that information relating roofing materials and their surfaces on an urban district does not currently exist in urban databases. In the city of Créteil, different urban data (historical urban evolution, land use...) are available but they are not sufficient to achieve our objective to evaluate roofing material emissions.

In this context, data acquired on Créteil have been adapted and transformed to provide new useful data that will be used in our work.

\subsection{Annual runoff rates and typical situations of zinc emission from roofing materials}

In the city of Créteil, zinc annual runoff rates have been produced for different metallic materials (Robert-Sainte et al., 2009) (see Table 2). We should note that zinc runoff rates from roof did not include atmospheric deposition. In fact, Robert-Sainte et al (2009) have firstly evaluated atmospheric input values on Plexiglas panels. Then, they have directly deduced these values from concentration levels before the calculation of zinc runoff rates.

The studied new stainless steel, coated steel, new zinc, new aluminium and coated aluminium samples were standard products. Thus, they are considered as representatives for the hole of Créteil. However, for the preweathered zinc, the process depends on the producer and the product.

Table 2: Typical situations of zinc emission (Robert-Sainte et al., 2009)

\begin{tabular}{|c|c|c|c|c|}
\hline \multicolumn{3}{|c|}{ Material } & \multirow{2}{*}{$\begin{array}{l}\text { Localisation on } \\
\text { the roof }\end{array}$} & \multirow{2}{*}{$\begin{array}{c}\text { Annual average } \\
\text { runoff rate } \\
\left(\mathrm{g} / \mathrm{m}^{2} / \text { year }\right) \\
(\mathrm{g} / \mathrm{ml} / \text { year } *)\end{array}$} \\
\hline Type & Age & Form & & \\
\hline \multirow{3}{*}{ Zinc natural } & \multirow{3}{*}{ New } & \multirow{3}{*}{ Principal component of zinc sheet } & Rooftop & \multirow{2}{*}{3.9} \\
\hline & & & Sealing element ${ }^{3}$ & \\
\hline & & & Gutter* & 0.87 \\
\hline Zinc old & 40 years & Principal component of zinc sheet & Gutter* & 0.81 \\
\hline \multirow{2}{*}{ Anthra zinc } & \multirow{2}{*}{ New } & \multirow{2}{*}{ Principal component of zinc sheet } & Rooftop & 2.3 \\
\hline & & & Gutter* & 0.50 \\
\hline Galvanised steel & New & $\begin{array}{l}\text { Principal component of the coating the } \\
\text { of galvanised steel sheet }\end{array}$ & Rooftop & 2.0 \\
\hline \multirow{2}{*}{ Lead } & New & Component of lead sheet & Rooftop & 0.052 \\
\hline & 50 years & Component of lead sheet & Rooftop & 0.11 \\
\hline \multirow{2}{*}{ Aluminium } & \multirow{2}{*}{ New } & Component of aluminium sheet & Rooftop & 0.034 \\
\hline & & Component of aluminium sheet & Gutter* & No emission \\
\hline Aluminium coated & New & Component of aluminium coated sheet & Gutter* & No emission \\
\hline \multirow{2}{*}{ Copper } & New & Component of copper sheet & Gutter* & 0.002 \\
\hline & 20 to 25 years & Component of copper sheet & Gutter* & 0.021 \\
\hline
\end{tabular}

The market share between the different producers is $70 \%$ for VMZINC, 20\% for RHEINZINK and $10 \%$ for the others (MSI, 2012). In Paris area, the market share of VMZINC is even higher (information given by producer). VMZINC produces two types of pre-weathered zinc: Anthra zinc and Quartz zinc. Robert-Sainte et al. (2009) only tested Anthra zinc. Literature data in other countries do not allow concluding on the difference of zinc runoff between anthra zinc and quartz zinc.

\subsection{Dividing the city into homogeneous urban units}

To develop the method to evaluate roofing material surfaces or lengths on the city scale, specific urban data are needed. Thus, a survey has been established by consulting different urban databases, scientific literature,

\footnotetext{
${ }^{2}$ IAU: Institut d'Aménagement et d'Urbanisme d'Ile-de-France: institute of planning and development for the Greater Paris region. http://www.iaurif.org/

${ }^{3}$ For sealing element and valley, no runoff rates data have been produced. Thus, we propose an approximation for these two values. For sealing element they have been approximated by the rooftop runoff value and valley it was approximated by the gutter one.
} 
technical documents and interviews. The results of this survey enable us to define new rules for identifying the use of a roofing material on the city scale. In what follows, rules will be described and applied to Créteil city.

\subsubsection{Rule 1: A specific roofing material distribution is associated to each "Building class"}

The choice of a roofing material depends on the building typology. For example, in France, individual housing roofs are mostly covered with concrete or clay tiles. In Créteil, a land use database named MOS-IAU is available. This database is very detailed and describes all types of land uses such as green space and roads. To optimize the use of this database for our objective, different operations have been elaborated (Belmeziti et al., 2013). The first one is to focus only on building land use which still very detailed. Then, the building land use data are organized by gathering all buildings with the same use of roofing materials. Therefore, new building types have been created called "Building class" characterized by a specific roofing material distribution. Thirteen "Building classes" have been created: individual houses, apartment, secondary activities, administrations, sports, commercial space, education, cultural, offices, health equipment, transport, other building (ex: jail), other equipment (water, gas...).

Finally, a new map of Créteil has been elaborated describing the different "Building classes" (see Figure 2). This map has been associated via QGIS ${ }^{4}$ software with a numerical cadastre named BD-topo database (IGN, 2008), which contains a vector description of the building layer. BD-topo database provides the roofing surface for each building. Thus, by crossing "Building classes" map and the BD-topo, roofing surface areas are computed for each "Building class".

\subsubsection{Rule 2: A specific roofing material distribution is associated to each historic urban area}

The spatial and temporal urban evolution of the city affects the use of roofing material. For example, in central Paris, roughly $40 \%$ of all roofing surfaces are covered with rolled zinc, due to the urban planning made by Haussmann in the 19's century (Gromaire et al., 2002). The city of Créteil is divided into four major historical urban areas: Old center, Mont Mesly, New Creteil I, New Créteil II. This division is however not perfectly relevant to identify roofing materials. The urban survey made in the city, enabled us to divide the city into 3 historical urban areas corresponding to different periods of construction (see Figure 2).

- Area 1 from 19th century to 1950: characterized by downtown and a majority of individual houses.

- Area 2 from 1951 to 1980: construction of economic buildings with several floors and flat roof.

- Area 3 from 1981 to 2008: great urbanization of the city (mainly apartment buildings) with specific requirement of the mayor: each new building should be with a pitched roof in order to get an urban continuity with the downtown. Architects who preferred flat roofs tried to build flat roof with slate or tile roof breaks.

\subsubsection{Rule 3: The town regulation framework allows/ prohibits roofing materials in the city.}

In central Paris, architectural rules concerning the protection of historical monuments and their environment prevent any changes for many years (Gromaire et al., 2002). In the city of Créteil, there is no specific recommendation for the roofing material use. The only restriction is the mayor requirements to have pitched roofs to preserve the identity of the old Créteil of the 19th century.

The application of the different rules enables us to produce two different maps. The first map is an historical map and the second one is the "Building classes" map (see Figure 2).

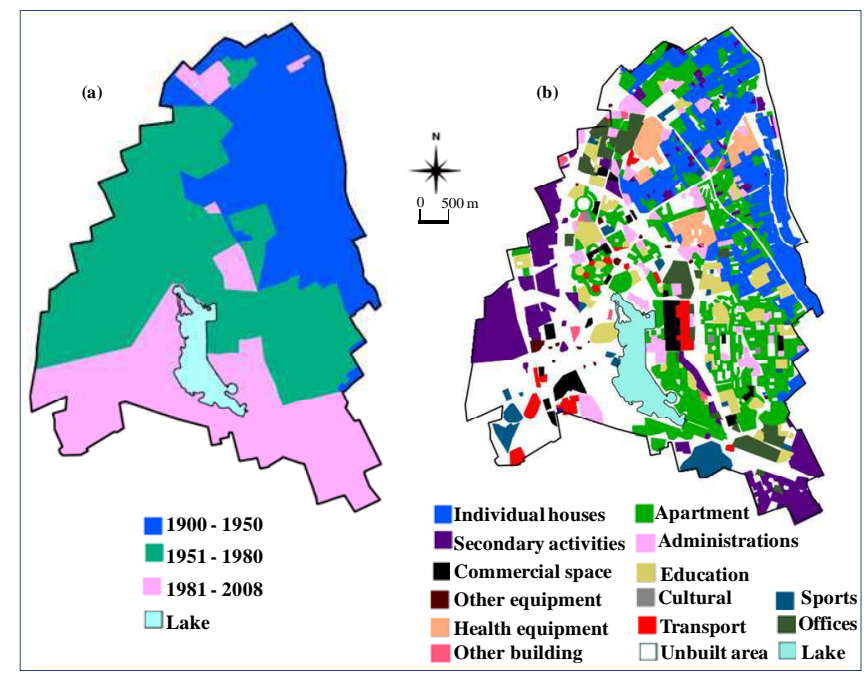

Figure 2: (a) Historical map (b) “Building classes” map

\footnotetext{
${ }^{4}$ Quantum GIS (often abbreviated QGIS) is a cross-platform free and open source desktop geographic information systems application that provides data viewing, editing, and analysis capabilities. http://www.qgis.org/
} 


\subsubsection{Homogeneous urban units}

By overlaying these two maps (see Figure 2); each building class located in an historical area is a homogeneous urban unit in terms of building types and historical location.

In what follows the term unit will be used. To optimize the computation time, only the most important "Building classes" corresponding to a cumulated surface of at least $95 \%$ of the total roofing surface of the considered historical area are selected (see Figure 3).

Three different units have been selected to study the influence of building typology and surfaces on the zinc emission:

Unit 1: "individual houses class" located in area 1 (58.5\% of the area 1 roofing surface)

Unit 2: "apartment class" located in area 1 (37\% of the area 1 roofing surface)

Unit 3: "health equipment class" located in area 1(4.5\% of the area 1 roofing surface). This unit has been selected because it presents many zinc roofs.

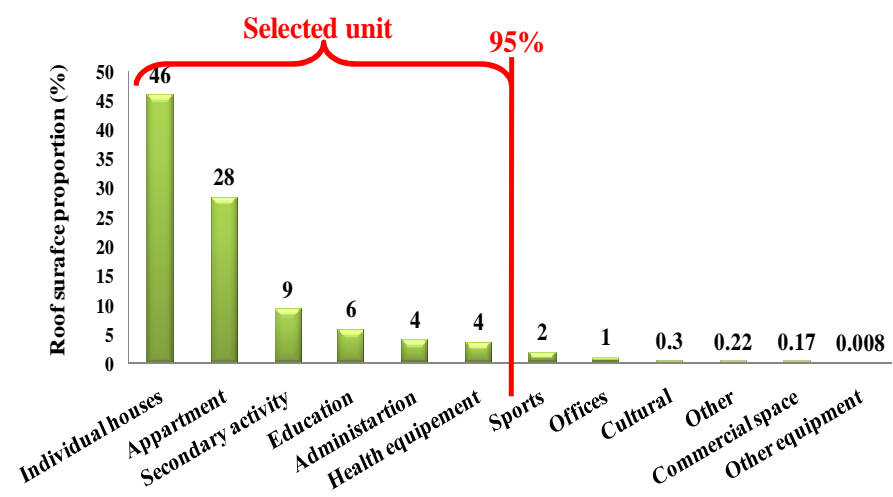

Figure 3: The distribution of roof surface "Building classes" in the area 1 (1900- 1950)

\subsection{Quantification of rooftop material class surfaces and their associated valley and gutter lengths}

This method is based on a stratified random sampling technique in conjunction with aerial photograph interpretation of the rooftop material class and their surfaces and measuring the gutter and valley lengths.

In this part, the statistical approach will be applied for the selected units. By overlying the unit map and the BDtopo database, the roof surface for each unit $\left(N\left(\mathrm{~m}^{2}\right)\right)$ is obtained. The sampling strategy is based on randomly generating independent buildings. Each selected building $(b)$ has a specific roofing material. So, a database of buildings sampled in the unit with their roof surfaces $S_{b}\left(\mathrm{~m}^{2}\right)$ is generated. By associating BD-topo and BDortho $^{5}$ (IGN, 2008), for each sampled building (b), its valley length $l_{v, b}(m)$ and gutter length $l_{g, b}(m)$ are measured with QGIS and its rooftop material class is identified by looking to the image. In the sample $s$ the total building surfaces $S_{s}\left(\mathrm{~m}^{2}\right)$, the total valley lengths $l_{v, s}(\mathrm{~m})$ and the total gutter lengths $l_{g, s}(\mathrm{~m})$ are evaluated.

Finally, for each rooftop material class $i$ in the sample, the rooftop surface area $S_{s, i}\left(\mathrm{~m}^{2}\right)$ and its proportion $p_{s, i}$ $(\%)$, the gutter length $l_{g, s, i}(m)$ and the valley length $l_{v, s, i}(m)$ are computed. These results are then extrapolated to the unit with uncertainty calculations.

\subsubsection{Uncertainty calculations}

The sampling strategy uncertainties were computed for:

- $p_{s, i}$ : proportion of rooftop material class $i$ in the sample $s$

- The ratio between the valley length for each material class $i$ and the total valley length in the sample $s$ :

$\mathrm{R}_{\mathrm{v}, \mathrm{s}, \mathrm{i}}=\frac{l_{v, s, i}}{l_{v, s}}$

- The ratio between the gutter length for each material class $i$ and the total gutter length in the sample $s$ :

$\mathrm{R}_{\mathrm{g}, \mathrm{s}, \mathrm{i}}=\frac{l_{g, s, i}}{l_{g, s}}$

The Theorem for Proportions (Saporta, 1990) is applied, in which the sampling distribution for samples with size $n \geq 30$ (generated without replacement) is approximately normal, so:

\footnotetext{
${ }^{5}$ BD-ortho images come from IGN's (Institut Géographique National) which contains digital colour ortho-photos with three or four (red-
} green-blue-near infrared) bands and with a $50 \mathrm{~cm}$ ground resolution. 


$$
\mathrm{T}_{\mathrm{s}, \mathrm{i}} \rightarrow N\left(T_{i} ; \sigma_{T_{i}}=\sqrt{\frac{T_{i}\left(1-T_{i}\right)}{n} \times\left(1-\frac{n}{N}\right)}\right)
$$

where $\mathrm{T}_{\mathrm{i}} \in\left\{p_{i} ; \mathrm{R}_{\mathrm{v}, \mathrm{i}} ; R_{\mathrm{g}, \mathrm{i}}\right\}, \mathrm{T}_{\mathrm{s}, \mathrm{i}} \in\left\{p_{s, i} ; \mathrm{R}_{\mathrm{v}, \mathrm{s}, \mathrm{i}} ; \mathrm{R}_{\mathrm{g}, \mathrm{s}, \mathrm{i}}\right\}$

$p_{i}$ : the material proportion in the unit

$R_{v, i}:$ the material valley ratio in the unit

$R_{g, i}:$ the material gutter ratio in the unit

The point estimate of $T_{i}$ is $T_{s, i}$ and an estimation of standard error is given by:

$$
\sigma_{T_{i}}=\sqrt{\frac{T_{s, i}\left(1-T_{s, i}\right)}{n} \times\left(1-\frac{n}{N}\right)}
$$

At the confidence-level coefficient of $\alpha=0.05$ :

$$
C I=T_{i} \in\left\lfloor T_{s, i}-1.96 \times \sigma_{T_{i}}, T_{s, i}+1.96 \times \sigma_{T_{i}}\right\rfloor
$$

Results are illustrated in Table 3.

\subsection{Quantification of rooftop material surfaces, gutter material lengths and the valley material lengths for the selected units}

A survey was made by conducting interviews with experts of the roofing material sector (industrials, masters of work, architects...). Different documents have been consulted: town planning regulation framework, construction laws, standardized technical documents (in France, DTU: Documents Techniques Unifiés), marketing research (MSI, 2006, 2012). A historical study was made concerning the roofing material evolution (appearance, disappearance, evolution characteristics ...). In fact, the rapid development of industrial technologies affects the use and the material characteristics. Thus, an historical table was elaborated for roofing material historical evolution.

The objective of this survey is to identify the different parameters influencing the choice of a material from the different material class varieties. Different hypotheses have been identified from this survey; they allow us to define rules. These latter enable us to get a first distribution of the material in the different roofing elements.

In what follows, the different rules to evaluate materials in the selected unit are described.

The first step was to cross roofing material historical evolution with the city of Créteil urban history. This work allows us to identify the roofing materials potentially existing in an historical area.

Figure 4 describes the history of the different materials found in the city of Créteil and which emit the zinc contaminant (Aocdtf, 1989; Lamesch, 2004; Hartmann, 2004, 2006; Invernizzi, 2000; Payet-Gaspard, 2012; Schonnenbeck and Neumann, 2013).

In addition, in France, roofing techniques are described in details in standardized technical documents (DTU), addressed to professional roofers. Indeed, all roofing techniques are indexed: materials that may be used and the way of their implementation (DTU 40.1, 40.2, 40.3, 40.4, 40.5 and 43). All constructions are expected to respect these reference documents. Thus, these documents have been used in order to identify the roofing material used for the different roofing elements. In DTU documents, gutter material is not specified for each rooftop material class. The roofer has the choice between five gutter materials: zinc, copper, stainless steel, PVC and aluminium. For metal rooftops, valley is considered as a part of the rooftop and thus has the same metal material, whereas for the other rooftop material classes, valley materials could be zinc or lead or the same material as the rooftop (tile, stales...).

Area 1
1900

Figure 4: The historical evolution of roofing material emitting of zinc 
Table3 : Rooftop surface area, gutter length and valley length computed for each material class for three units: individual houses, apartment and health equipment classes located in area $1(1900-1950)$

\begin{tabular}{|c|c|c|c|c|c|c|c|c|c|}
\hline \multirow[t]{2}{*}{$\begin{array}{l}\text { Material } \\
\text { class }\end{array}$} & \multicolumn{3}{|c|}{$\begin{array}{c}\text { Rooftop surface } \\
\text { area } S_{i} \pm \text { CI }\left(\mathbf{m}^{2}\right) \\
\left(p_{s, i} \pm \text { CI }(\%)\right)\end{array}$} & \multicolumn{3}{|c|}{$\begin{array}{c}\text { Gutter length } l_{g, i} \pm \mathbf{C I}\left(\mathbf{m}^{2}\right) \\
\left(R_{g, s, i} \pm \mathbf{C I}(\%)\right)\end{array}$} & \multicolumn{3}{|c|}{$\begin{array}{c}\text { Valley length } l_{v, i} \pm \mathbf{C I}\left(\mathbf{m}^{2}\right) \\
\left(R_{v, s, i} \pm \mathbf{C I}(\%)\right)\end{array}$} \\
\hline & Unit 1 & Unit 2 & Unit 3 & Unit 1 & Unit 2 & Unit 3 & Unit 1 & Unit 2 & Unit 3 \\
\hline Tile & $\begin{array}{c}278648 \pm 21123 \\
(83.2 \pm 7.58)\end{array}$ & $\begin{array}{c}91793 \pm 9638 \\
(43.32 \pm 10.50) \\
\end{array}$ & $\begin{array}{c}5100 \pm 123 \\
(19.65 \pm 2.42) \\
\end{array}$ & $\begin{array}{r}71676 \pm 5143 \\
(85.31 \pm 7.18) \\
\end{array}$ & $\begin{array}{l}22298 \pm 2069 \\
(74.12 \pm 9.28) \\
\end{array}$ & $\begin{array}{c}1033 \pm 7 \\
(66.66 \pm 0.68) \\
\end{array}$ & $\begin{array}{c}7060 \pm 568 \\
(80.43 \pm 8.04) \\
\end{array}$ & $\begin{array}{c}1757 \pm 147 \\
(80.56 \pm 8.39) \\
\end{array}$ & $\begin{array}{c}163 \pm 7 \\
(91 \pm 4.3) \\
\end{array}$ \\
\hline Coated steel & $\begin{array}{c}845 \pm 9 \\
(0.25 \pm 1.02) \\
\end{array}$ & - & $\begin{array}{c}851 \pm 9 \\
(3.28 \pm 1.08) \\
\end{array}$ & $\begin{array}{c}335 \pm 4 \\
(0.40 \pm 1.28) \\
\end{array}$ & - & $77 \pm 3(5 \pm 3.9)$ & - & - & - \\
\hline $\begin{array}{l}\text { Galvanized } \\
\text { steel }\end{array}$ & $\begin{array}{c}5306 \pm 134 \\
(1.58 \pm 2.53)\end{array}$ & - & - & $\begin{array}{c}1280 \pm 32 \\
(1.52 \pm 2.48)\end{array}$ & - & - & - & - & - \\
\hline $\begin{array}{l}\text { Bituminous } \\
\text { flat roof }\end{array}$ & $\begin{array}{c}5409 \pm 138 \\
(1.61 \pm 2.56)\end{array}$ & $\begin{array}{l}17813 \pm 1047 \\
(8.41 \pm 5.88)\end{array}$ & $\begin{array}{c}6151 \pm 159 \\
(23.70 \pm 2.59)\end{array}$ & - & - & - & - & - & - \\
\hline $\begin{array}{l}\text { Gravel flat } \\
\text { roof }\end{array}$ & $\begin{array}{c}6406 \pm 178 \\
(1.91 \pm 2.78)\end{array}$ & $\begin{array}{l}68017 \pm 6729 \\
(32.10 \pm 9.89)\end{array}$ & $\begin{array}{l}11176 \pm 336 \\
(43.06 \pm 3.01)\end{array}$ & - & - & - & - & - & - \\
\hline Zinc & $\begin{array}{c}7379 \pm 220 \\
(2.20 \pm 2.98)\end{array}$ & $\begin{array}{l}28176 \pm 2027 \\
(13.30 \pm 7.19)\end{array}$ & $\begin{array}{c}2299 \pm 40 \\
(8.86 \pm 1.73)\end{array}$ & $\begin{array}{c}2506 \pm 86 \\
(2.98 \pm 3.45)\end{array}$ & $\begin{array}{c}6703 \pm 591 \\
(22.28 \pm 8.82)\end{array}$ & $\begin{array}{c}346 \pm 6 \\
(22.34 \pm 1.74)\end{array}$ & $\begin{array}{c}137 \pm 3 \\
(1.56 \pm 2.51)\end{array}$ & $\begin{array}{c}424 \pm 36 \\
(19.44 \pm 8.39)\end{array}$ & $\begin{array}{c}16 \pm 0.3 \\
(8.9 \pm 1.87)\end{array}$ \\
\hline Slates & $\begin{array}{c}20552 \pm 1000 \\
(6.14 \pm 4.86)\end{array}$ & - & - & $\begin{array}{c}6510 \pm 353 \\
(7.75 \pm 5.42)\end{array}$ & - & - & $\begin{array}{c}1581 \pm 123 \\
(18.01 \pm 7.79)\end{array}$ & - & - \\
\hline Shingles & $\begin{array}{l}10405 \pm 366 \\
(3.11 \pm 3.52)\end{array}$ & $\begin{array}{c}6102 \pm 216 \\
(2.88 \pm 3.54)\end{array}$ & $\begin{array}{c}375 \pm 3 \\
(1.45 \pm 0.73)\end{array}$ & $\begin{array}{c}1708 \pm 49 \\
(2.03 \pm 2.86)\end{array}$ & $\begin{array}{c}1081 \pm 43 \\
(3.6 \pm 3.94)\end{array}$ & $9 \pm 4(6 \pm 4.3)$ & - & - & - \\
\hline
\end{tabular}




\subsubsection{Rules linking the rooftop material class to the rooftop material}

Table 3 and Table 2 show that the roofing material classes that emit zinc are galvanized steel, zinc, and coated steel. The zinc material class presents different material varieties: natural zinc, pre-weathered zinc, coated zinc and coloured zinc. During the identification of rooftop material from aerial images, all collared materials were classified into "other material class". Thus, collared zinc will be ignored. To distinguish between the other zinc varieties, other information is needed. The selected units: individual housing class, apartment class and health equipment class, are located in area 1. In this latter, by looking to Figure 4, the only zinc existing variety is natural zinc. Buildings located in area 1 (1900-1950) are however old and their roofing materials have probably been renewed at least once time. The zinc cycle life is about 50 years (MSI, 2006). The zinc producers (e.g. VMZINC) say that old natural zinc renewal is usually done with the same zinc variety. To conclude, in area 1 the zinc variety used is natural zinc. The natural zinc age is less than 58 years if we consider that it was renewed once. For coated and galvanized steel they are appeared in roofs in 1975, their age is about 33 years. The life cycle of steel is about 100 years (MSI, 2006).

\subsubsection{Rules linking the rooftop material to the gutter material}

Gutter materials are of six different types (DTU). The used zinc is mainly natural zinc. The survey shows that today, the gutter market in France is divided between three principal materials: natural zinc, PVC and coated aluminium. The other gutter materials represent only $5 \%$ of the market and therefore, their contribution can be neglected in a first approach. Figure 4 shows that PVC appeared in the 1980's and coated aluminium in 2000. Therefore, in area 1 (1900-1950) these two materials are not originally present: the existing gutter materials are copper and natural zinc. If we consider the cycle life of natural zinc (50 years) and of copper (70 years) (MSI, 2006), thus, the gutters have been renewed at least once. Zinc and copper are noble materials, gutter with those materials are generally renewed by the same material (according to interview with roofing material experts). In selected units, gutters are linked to the rooftop material: tile, coated steel, galvanized steel zinc, slates and shingles. Coated steel and galvanized steel are economic roofing solution appeared in 1975. Such roofs are strongly correlated with PVC gutters, in the proportion of about $80 \%$ in PVC, the $20 \%$ remaining being mostly in natural zinc (according to interview with roofing material experts). For natural zinc rooftop, the gutter material is old natural zinc. For shingles which are mainly used during the 1980's and are considered as economic materials, the gutter material distribution is probably the same as for coated steel. Finally, for old tile and old slates rooftops, the considered materials are natural zinc and copper. Copper is an expensive material and its use in gutter will be very limited compared to natural zinc. In addition, as our objective is to evaluate zinc emission, we assume, using a first overestimation approach (Belmeziti et al., 2013), that gutter material distribution for old tile rooftop is $95 \%$ in natural old zinc and 5\% in old copper.

\subsubsection{Rules linking the rooftop material to the valley material}

The survey made with the actors of the roofing material sector shows that for metal rooftop, valley materials are the same as the rooftop materials. The obtained rule is: "For metal rooftop, the valley is a part of the rooftop". Thus, valley will be computed only for non metal rooftop (tile, slates, shingle). In this case, valley material could be zinc or lead or the rooftop material (tile, slates, and shingle). The survey shows that the zinc used for valleys is then natural zinc. For lead, it was used in very old building built before the $19^{\text {th }}$ century. In addition, in area 1 , the oldest building is dating from 1900 and then lead in valley was not used. To have an estimation of the tile valley proportion, natural zinc valley proportion and slates valley proportion, we adopt here again an overestimation approach (Belmeziti et al., 2013). It means that, as our objective is to evaluate zinc emission, the quantification of valley lengths will be majored by considering that all valleys are made in natural zinc.

\subsection{Zinc annual flow calculation for the selected units}

The zinc annual flow emits by rooftop, gutter and valley material will be computed using the following equation:

$$
F_{\text {zinc, roof.location }}=\sum_{i=\text { material }}\left(D_{\text {roof.location }, i} \times r_{\text {zinc.roof.location }, i}\right)
$$

Where $D$ represents the roof location dimension: area for rooftop $\left(\mathrm{m}^{2}\right)$ and length for gutter and valley $(\mathrm{m})$ ). $\boldsymbol{r}_{\text {zinc, roof location }}$ is the zinc annual runoff rate emitted by the different roofing material elements. Runoff rates are taken from Table 2 . 


\section{Results and discussion}

The evaluation of zinc emissions from roofing materials on a city scale shows that zinc emissions depend not only on the surface of the considered unit but, also on the building typology (see Table 4). In addition, the principal source of zinc emissions is the rooftop. However, other elements of the roof such as gutters and valleys may contribute significantly to zinc emissions. For instance, for the individual housing unit with rooftops with a majority of tiles ( $83 \%$ tile roof, $2 \%$ zinc roof), the principal source of zinc emissions is the gutter $(23.7 \%$ of the whole zinc emissions from the three units versus $15.7 \%$ providing by rooftop) (see Figure 5). Besides, although the zinc emissions from valleys are the lowest (3.23\% of the total for the three units), the valley emissions in the individual houses $(2.64 \%$ of the total) are of the same order of magnitude as the rooftop emissions in the health equipment unit (3.7\%). Thus, the zinc emission from tightness elements such as valleys should not be neglected. Therefore, the contribution of the different elements of the roof (rooftop, gutter and valley) to zinc emissions strongly depends on building typology and the unit area.

The validation of this method is difficult. In fact, it is impossible to experimentally measure roof emissions on a city scale. In addition, stormwater collected in the drainage systems are a mixture of the different types of urban surfaces. Moreover, in Créteil, no experimental data of zinc emissions from roofs or from other sources have been found.

Table 4: Results for annual zinc flow for the three selected units

Figure 5: Distribution of the total zinc emissions from the three units from the different sources

\begin{tabular}{|c|c|c|c|c|}
\hline $\begin{array}{c}\text { Unit } \\
\text { (area 1) }\end{array}$ & $\begin{array}{c}\text { Roof } \\
\text { Area }\left(\mathbf{m}^{2}\right)\end{array}$ & $\begin{array}{c}\text { Roof area } \\
\text { distribution } \\
(\boldsymbol{\%})\end{array}$ & $\begin{array}{c}\text { Annual zinc } \\
\mathbf{f l o w} \mathbf{+ C I} \\
(\mathbf{k g} / \mathbf{y e a r})\end{array}$ & $\begin{array}{c}\text { Zinc } \\
\text { emission } \\
\text { distribution } \\
(\boldsymbol{\%})\end{array}$ \\
\hline $\begin{array}{c}\text { Individual } \\
\text { houses }\end{array}$ & 334950 & 58.5 & $111.44 \pm 5.72$ & 42.1 \\
\hline Apartment & 211901 & 37.0 & $142.65 \pm 10.71$ & 53.8 \\
\hline $\begin{array}{c}\text { Health } \\
\text { equipment }\end{array}$ & 25954 & 4.5 & $10.91 \pm 0.18$ & 4.1 \\
\hline Total & 572805 & 100 & $265 \pm 16.62$ & 100 \\
\hline
\end{tabular}

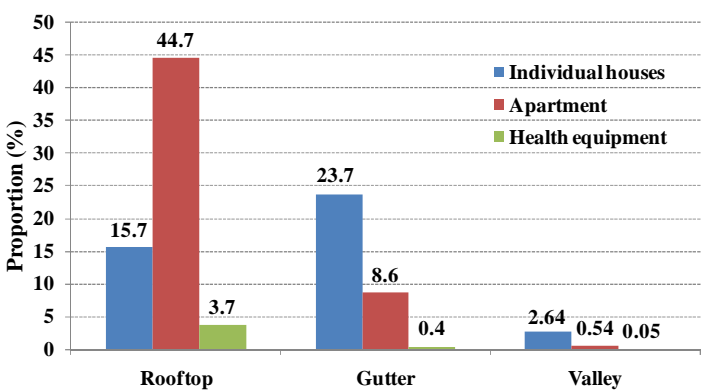

Nevertheless, some literature zinc fluxes data can be found. In fact, zinc emissions can be measured in some experimental roof runoff, sometimes with a rough extrapolation to the whole roofing area of a catchment scale. In addition, measurements can be made in the stormwater sewer on a catchment scale.

Thus, annual zinc runoff rates from roofs, computed in this study, were compared to other values collected in the literature (see Table 5). We should note that annual zinc runoff load data are very limited in the literature. The comparison shows that results obtained from this method are promising.

Table 5: Comparison of annual zinc runoff rates for different sites and different sources

\begin{tabular}{|c|c|c|c|}
\hline \multirow{2}{*}{ Sources } & $\begin{array}{c}\text { Mean Zinc annual } \\
\text { runoff rates } \\
\left(\mathbf{m g} / \mathbf{m}^{2} / \mathbf{y} \text { ear }\right)\end{array}$ & Site location & References \\
\hline \multirow{3}{*}{ Roofs } & $333-673$ & Créteil (France) & This study \\
\cline { 2 - 4 } & 478 & Residential site: 3.3\% of zinc roofs (Nantes, France) & (Lamprea, 2009) \\
\hline \hline \multirow{4}{*}{\begin{tabular}{c} 
Atmosphere \\
\cline { 2 - 4 }
\end{tabular}} & 1062 & Residential site: about 50\% of zinc roofs (Paris, France) & (Thévenot et al., 2007) \\
\cline { 2 - 4 } & 34.2 & Créteil (France) & (Robert-Sainte et al., 2009) \\
\hline \hline \multirow{2}{*}{$\begin{array}{c}\text { Stormwater } \\
\text { on a } \\
\text { catchment } \\
\text { scale }\end{array}$} & $15-140$ & France & $\begin{array}{c}\text { (Azimi et al., 2005; Bressy, 2010; } \\
\text { Garnaud et al., 1999; Lamprea, } \\
\text { 2009; Sabin et al., 2005) }\end{array}$ \\
\cline { 2 - 4 } & $240-430$ & Residential site: 30\% of zinc roofs (Noisy-le-Grand, France) & (Bressy, 2010) \\
\cline { 2 - 4 } & $4-80$ & Residential (Florida, USA) & (Wong et al., 2000) \\
\cline { 2 - 4 } & 39.8 & Residential site: 3.3\% of zinc roofs (Nantes, France) & (Lamprea, 2009) \\
\hline \multirow{2}{*}{\begin{tabular}{c} 
nyyn \\
\cline { 2 - 4 }
\end{tabular}} & 50.2 & Mixed site (Nantes, France) & (Becouze, 2010) \\
\hline
\end{tabular}

In Table 5, the mean zinc annual runoff rates from roofs have been elaborated by a rough extrapolation on the catchment scale of data measured from some experimental roofs. For stormwater catchment, measurements have been taken in separate sewer systems. This latter contains mixed urban runoff sources (roof, green space, road, sewer transfer...). Thus, the zinc runoff rates computed correspond to the whole zinc emissions on a catchment scale provided by different urban sources. In France, a residential site with $3.3 \%$ of zinc roof emits 478 $\mathrm{mg} / \mathrm{m}^{2} /$ year and a residential site with $50 \%$ of zinc roof emits $1062 \mathrm{mg} / \mathrm{m}^{2} /$ year. Therefore, values computed in this study belong to the range elaborated for the different sites. Measurements of zinc in stormwater have been taken in different sites in France and the USA. For sites with a high zinc roof density (30\%), zinc emissions in stormwater on a catchment scale are very high. For instance, the zinc emission values measured in stormwater 
catchments are evaluated throughout the whole catchment surface area, contrary to our study where the values are computed only for the roof area. Therefore, roofs are an important source of zinc emissions compared to the zinc emissions in stormwater on the catchment scale. Is important to note that this observation also remains valid even in the case where the zinc roof proportion is small. Finally, even if rooftops are the principal source of roof runoff contamination, the emissions of the other different roof elements (e.g. gutter and valley) should not be neglected.

A deeper validation of this method could be done by its integration into a larger substance flow analysis model that estimates the whole contaminant emission provided by different sources on the city scale. But, even with such an approach, this validation may create a difficulty to describe the processes within the sewage network.

In the city of Créteil, Robert-Sainte (2009) evaluated the zinc annual atmospheric deposition rate (34.2 $\mathrm{mg} / \mathrm{m}^{2} /$ year). This value belongs to the range elaborated for different sites in France. Roofs are a large source of zinc emissions in Créteil compared to the atmosphere: industrial activities are very limited (14\%of Créteil area) and consequently, the related zinc emissions in the atmosphere.

\section{Conclusions}

A new methodology evaluating contaminant flow emissions on the city scale has been developed by studying the zinc emissions in the city of Créteil. It is based on using and adapting existing urban databases in conjunction with a statistical approach. This method contributes to an assessment of pollutant flows on the city scale and then, the impact of a city or an urban area on the environment can be evaluated.

Our method can be used as a decision-making tool by urban planners at three levels to implement policies in order to reduce roofing pollutants emissions. This innovative method will firstly allow them to assess the state of the emissions for existing roofs all over the city. They will then be able to define a plan of renewing roofing materials on the urban scale. And finally, it will be also possible to define a roofing material choice strategy for the construction in new urban areas.

To conclude, some considerations should be taken into account to apply this method to other cities.

Some adaptations need specific work. The historical urban evolution of the city map has to be elaborated for each studied city. This type of map can be available in the municipality library databases. It is also important to identify the different existing rules in the city related to the roofing materials use such as the town planning regulation framework (e.g. the Local Urban Planning scheme) and construction regulations. For the Ile-deFrance cities, the building class databases are the same as Créteil. Elsewhere, land use databases are available but present some differences versus MOS-IAU. Whatever the land use database, it should be reorganized to get the thirteen "Building classes" created from the MOS-IAU land use database.

Other elements of the method can be applied with minor changes. Most of the rules linking the rooftop material classes and the material of the different roofing elements could be directly applied. The historical evolution of the roofing material table can be used in any city. Other rules are specific to Créteil, but they highlight some principles which can be adapted to other cities. The renewal process of the material because of its age strongly depends on the historical evolution of the city. Moreover, the specificities of the city can be used to optimize the computing process. For instance, one can find texts prohibiting roofing materials in urban planning city regulations: the number of roofing materials to be taken into account is therefore reduced.

Finally, runoff rates for different contaminants emitted from roofing elements could be used in other cities except for those where very specific local conditions may affect emission processes. Actually, the practical table of runoff rates for different contaminants presented in this paper is not complete. The production of more runoff rates is still needed.

\section{Acknowledgements}

This study has been conducted as part of the OPUR research program. The authors gratefully acknowledge the Centre Scientifique et Technique du Bâtiment (CSTB) for their financial support.

\section{References}

Aocdtf, 1989, Encyclopédie des métiers - L'art du Couvreur, p. 1872.

Azimi S, Rocher V, Muller M, Moilleron R, and Thevenot DR (2005) Sources, distribution and variability of hydrocarbons and metals in atmospheric deposition in an urbanarea (Paris, France): Science of the total environment, v. 337 (1$3)$.

Becouze C (2010). Caractérisation et estimation des flux de substances prioritaires dans les rejets urbains par temps de pluie sur deux bassins versants expérimentaux, L'institut national des sciences appliquées de Lyon.

Belmeziti A, Coutard O, and de Gouvello B (2013) A New Methodology for Evaluating Potential for Potable Water Savings (PPWS) by Using Rainwater Harvesting at the Urban Level: The Case of the Municipality of Colombes (Paris Region) Water, v. 5, p. 312-326.

Bergamasco L, and Asinari P (2011) Scalable methodology for the photovoltaic solar energy potential assessment based on available roof surface area: Application to Piedmont Region (Italy): Solar Energy, v. 85, p. 1041-1055. 
Bertling S, Odnevall Wallinder I, Leygraf C, and Berggren Kleja D, (2006) Occurence and fate of corrosion-induced zinc in runoff water from external structures Science of the Total Environment, v. 367, p. 908-923.

Bowen C and de Groot P.. (2000) Health safety and the enviroment-aqueous leaching of pac's from bitumen, in B. C. A., ed., Barcelona- Spain, $2^{\text {nd }}$ Eurasphalt \& Eurobitume Congress Barcelona 2000.

Bressy A (2010) Flux de micropolluants dans les eaux de ruissellement urbaines. Effets de différents modes de gestion deseaux pluviales Université PARIS-EST, $332 \mathrm{p}$.

Burkhardt M, Kupper T, Hean S, Haag R, Schmid P, Kohler M and Boller M (2007) Biocides used in building materials and their leaching behavior to sewer systems: Water Science and Technology, v. 56, p. 63-67.

Ellis JB and Hvitved Jacobsen T (1996) Urban drainage impacts on receiving waters.: Journal of Hydraulic Research, v. 34 (6), p. 771-783.

Förster J (1996) Patterns of roof runoff contamination and their potential implications on practice and regulation of treatment and local infiltration": Water, Science and Technology", v. 33 (6), p. 39 - 48.

Garnaud S, Mouchel JM, Chebbo G, and Thévenot DR (1999) Heavy metal concentrations in dry and wet atmospheric deposits in Paris district : comparison with urban runoff: The Science of the total environment, v. 235 (1-3).

Gill SE, Handley JF, Ennos AR and Pauleit AR (2006) Adapting Cities for Climate Change: The Role of the Green Infrastructure: Built environment, v. 33(1), p. 115-133.

Gromaire MC, Chebbo G and Constant A, (2002) Incidence of zinc roofing on urban runoff pollutant loads: The case of Paris: Water, Science and Technology, v. 45, p. 113-112.

Gromaire MC, Robert-Sainte P, Bressy A, Saad M, de Gouvello B, and Chebbo G (2011) Zn and Pb emissions from roofing materials-Modelling and mass balance attempt at the scale of a small urban catchment: Water Science and Technology, v. 63, p. 2590-2597.

Gromaire-Mertz MC, Garnaud S, Gonzalez A, and Chebbo G (1999) Characterisation of urban runoff pollution in Paris: Water, Science and Technology, v. 39(2), p. 1 - 8.

Hartmann G, (2004) L'aluminium historique: http://www.hydroretro.net/etudegh/aluminium_historique.pdf

Hartmann G, (2006) L'acier historique: http://www.hydroretro.net/etudegh/acier_historique.pdf

$\mathrm{He}$ W, Odnevall Wallinder I and Leygraf C (2001) A comparison between corrosion rates and runoff rates from new and aged copper and zinc as roofing material: Water, Air and Soil Pollution, v. Focus 1, p. 67 - 82.

IGN ( 2008) Institut national de l'information géographique et forestière: $\underline{w w w . i g n . f r}$.

INSEE (2008) (Institut national de la statistique et des études économiques): http://www.recensement2008.insee.fr/chiffresCles.action?zoneSearchField=CRETEIL\&codeZone=94028-COM\&idTheme $=3$.

Invernizzi R, (2000) Les couvertures métalliques : matériaux et techniques, L'inox en couverture, Paris, Section française de l'Icomos, p. 169-174.

Izquierdo S, Rodrigues M, and Fueyo N (2008) A method for estimating the geographical distribution of the available roof surface area for large-scale photovoltaic energy-potential evaluations: Solar Energy, v. 82, p. 929-939.

Jungnickel C, Stock F, Brandsch T and Ranke J (2008) Risk assessment of biocides in roof paint - Part 1: Experimental determination and modelling of biocides leaching from roof paint: Environmental science and pollution research, $\mathrm{v}$. 15 (3) p. $258-265$

Lamesch J (2004) Histoire mondiale de la galvanisation: Arcelor.

Lamprea K (2009) Caractérisation des métaux traces, hydrocarbures aromatiques polycycliques et pesticides transportés par les retombées atmosphériques et les eaux de ruissellement dans les bassins versants séparatifs péri-urbains.

Le Bris A, and Robert-Sainte P (2009) Classification of roof materials for rainwater pollution modelization: http://www.isprs.org/proceedings/XXXVIII/1_4_7-W5/paper/LE_BRIS-152.pdf

Leuenberger-Minger AU, Faller M and Richner P (2002) Runoff of copper and zinc caused by atmospheric corrosion Materials and Corrosion, v. 53, p. 157-164.

MSI (2006) MSI Etude: le marché des matériaux de couverture des toits en France, MSI Marketing Research for Industry Ltd.

MSI (2012) Marché des Produits de Couverture de Toit en France 2012, Nouvelles tendances et prévisions., MSI Marketing Research for Industry Ltd.

Odnevall Wallinder I, Verbiest P, He W and Leygraf C (2000) Effects of exposure direction and inclination on the runoff rates of zinc and copper roofs: Corrosion Science, v. 42, p. 1471 - 1487.

Odnevall Wallinder I, Bertling S and Leygraf C (2004) Environmental interaction of copper and zinc released from building materials as a result of atmospheric corrosion: Metal 58 Jahrgang, p. 557 - 560.

Odnevall Wallinder I, Leygraf C, Karlen C, Heijerick D and Janssen CR (2001) Atmospheric corrosion of zinc-based materials: runoff rates, chemical speciation and ecotoxicity effects: Corrosion Science, v. 43, p. 809-816.

Odnevall Wallinder I, Verbiest P, He W and Leygraf C (1998) The influence of patina age and pollutant levels on the runoff rate of zinc from roofing materials": Corrosion Science, v. 40, p. 1977-1982.

Payet-Gaspard P (2012) Célébration du 100e anniversaire de l'acier inoxydable : L'histoire de sa création, Les grandes étapes par secteur, Son avenir: La revue spécialisée du nickel et de ses applications.

Quek U and Förster J (1993) Trace metals in roof runoff: Water, Air and Soil Pollution, v. 68, p. 373 - 389.

Robert-Sainte P (2009) Contribution des matériaux de couverture à la contamination métallique des eaux de ruissellement": Sciences et Techniques de l'Environnement thesis, Université PARIS-EST, Paris, 335 p.

Robert-Sainte P, Gromaire MC, de Gouvello B, Saad M and Chebbo G (2009) Annual metallic flows in roof runoff from different materials: test bed scale in Paris Conurbation: Environmental Science and Technology.

Sabin LD, Lim JH and Stolzenbach KD (2005) Contribution of trace metals from atmospheric deposition to stormwater deposition in a small impervious urban catchment: Water Research, v. 39 (16).

Saget A, Chebbo G and Desbordes M (1995) Urban discharges during wet weather - what volumes have to be treated: Water Science and Technology, v. 32(1), p. 225-232. 
Saporta G (1990) Probabilités analyse des données et statistiques: Paris (ed) Editions technip.

Schoknecht U, Gruycheva J, Mathies H, Bergmann H and Burkhardt M (2009) Leaching of Biocides Used in Facade Coatings under laboratory Test Conditions: Environmental Science \& Technology, v. 43, p. 9321-9328.

Schonnenbeck M and Neumann F (2013) Histoire du zinc, sa production, sa mise en oeuvre, RHEINZINK.

Thévenot DR, Moilleron R, Lestel L, Gromaire MC, Rocher V, Cambier P, Bonté P and Colin JL (2007) Critical budget of metal sources and pathways in the Seine River basin (1994-2003) for $\mathrm{Cd}, \mathrm{Cr}, \mathrm{Cu}, \mathrm{Hg}, \mathrm{Ni}, \mathrm{Pb}$ and $\mathrm{Zn}$ : Science of the total environment, v. 375, p. 180-203.

Van de Voorde A (2012) Incidence des pratiques d'entretien des toitures sur la qualité des eaux de ruissellement - Cas des traitements par produits biocides, Université PARIS-EST, Paris.

Van de Voorde A, Lorgeoux C, Gromaire MC and Chebbo G (2012) Analysis of quaternary ammonium compounds in urban stormwater samples: Environmental Pollution, v. 164, p. 150-157.

Wilson DN (2003) Atmospheric corrosion of lead, Release of metals due to corrosion of materials, Munich, Germany.

Wong T, Breen P and Lloyd S (2000) Water sensitive road design- Design options for improving stormwater quality of road runoff, Cooperative research centre for catchment hydrology. 